\title{
Use of the lambda Red recombinase system to produce recombinant prophages carrying antibiotic resistance genes Ruth Serra-Moreno ${ }^{1}$, Sandra Acosta1, Jean Pierre Hernalsteens ${ }^{2}$, Juan Jofre ${ }^{1}$ and Maite Muniesa*1
}

\author{
Address: ${ }^{1}$ Department of Microbiology. Faculty of Biology. University of Barcelona. Diagonal 645. E-08028 Barcelona. Spain and ${ }^{2}$ Viral Genetics \\ Laboratory, Faculty of Sciences, Vrije Universiteit Brussel, Pleinlaan 2, B-1050 Brussel, Belgium \\ Email: Ruth Serra-Moreno - ruthserra@ub.edu; Sandra Acosta - salmosandra@hotmail.com; Jean Pierre Hernalsteens - jphernal@vub.ac.be; \\ Juan Jofre - jjofre@ub.edu; Maite Muniesa* - mmuniesa@ub.edu \\ * Corresponding author
}

Published: 19 September 2006

BMC Molecular Biology 2006, 7:31 doi:10.1 |86/147|-2199-7-31
Received: 30 June 2006

Accepted: 19 September 2006

This article is available from: http://www.biomedcentral.com/147I-2199/7/3I

(c) 2006 Serra-Moreno et al; licensee BioMed Central Ltd.

This is an Open Access article distributed under the terms of the Creative Commons Attribution License (http://creativecommons.org/licenses/by/2.0), which permits unrestricted use, distribution, and reproduction in any medium, provided the original work is properly cited.

\begin{abstract}
Background: The Red recombinase system of bacteriophage lambda has been used to inactivate chromosomal genes in $E$. coli K-12 through homologous recombination using linear PCR products. The aim of this study was to induce mutations in the genome of some temperate Shiga toxin encoding bacteriophages. When phage genes are in the prophage state, they behave like chromosomal genes. This enables marker genes, such as antibiotic resistance genes, to be incorporated into the stx gene. Once the phages' lytic cycle is activated, recombinant Shiga toxin converting phages are produced. These phages can transfer the marker genes to the bacteria that they infect and convert. As the Red system's effectiveness decreased when used for our purposes, we had to introduce significant variations to the original method. These modifications included: confirming the stability of the target stx gene increasing the number of cells to be transformed and using a three-step PCR method to produce the amplimer containing the antibiotic resistance gene.

Results: Seven phages carrying two different antibiotic resistance genes were derived from phages that are directly involved in the pathogenesis of Shiga toxin-producing strains, using this modified protocol.
\end{abstract}

Conclusion: This approach facilitates exploration of the transduction processes and is a valuable tool for studying phage-mediated horizontal gene transfer.

\section{Background}

The analysis of microbial sequences has revealed that a substantial fraction of the genome of some bacteria corresponds to prophage DNA $[1,2]$. Such prophage DNA is inserted into the bacterial chromosome after infection by free phage particles. Bacteiophages have recently regained part of their former importance, but now with a medical and ecological focus.
Phage $\lambda$ DNA integrates into host DNA at one preferential site in Escherichia coli. This integration occurs through homologous recombination, mediated by the action of site-specific recombinases [3]. Bacteriophage can be released from cells containing an intact prophage through a process called induction. In this process, the prophage genes required for lytic growth are turned on, and progeny virions are produced and released from the cell. Cells car- 
rying a prophage are called 'lysogens' because of their potential to be induced and to lyse $[2,4]$. Most phage genes, including those required for lytic growth and virion production, are turned off in integrated prophages. However, prophages express regulatory proteins involved in the maintenance of the lysogenic state and 'lysogenic conversion' genes which alter the properties of the host bacterium. The products of these genes may have strong effects on the host bacterium, which can have its phenotype modified by expression of genes encoded by the prophage. These changes range from protection against further phage infection to increasing the virulence of a pathogenic host.

The presence or absence of prophages can account for much of the variation among individuals within a bacterial species. In addition, phages are likely to be important vehicles for horizontal transfer of genetic information between bacteria [2,5-7]. Clearly, to understand fully the role of phage-mediated gene transfer in the evolution of pathogenic bacteria, it is essential to study and understand the mechanisms of phage-mediated gene transfer itself.

To evaluate the mechanisms of lysogeny and phage-mediated horizontal gene transfer, recombinant phages carrying a marker gene, such as GFP (green fluorescent protein) [8] or antibiotic resistance cassettes [9], have been proposed as a useful tool. Such phages would convert the host bacteria after infection and integration, making the lysogens easy to detect in further studies.

A number of general allele replacement methods can be used to generate recombinant stx-phages. Some of these require creating a gene disruption in a suitable suicide plasmid before recombining it into the chromosome. The key to this procedure involves the use of vectors that cannot replicate under conditions used for selection of the cointegrates. Examples of such vectors for $E$. coli include ColE1-derived plasmids, which do not replicate in polA mutants [10], a temperature-sensitive pSC101 replicon [11], and a phagemid-based vector [12]. The application of pir-dependent vectors, as used to generate $\phi 3538$, another stx::cat recombinant phage [9], and repA-dependent broad-host-range plasmids for use in Gram-positive bacteria [13], have also been described. The suicide plasmid carrying the cloned mutant sequences is transferred in the host cells. At the non-permissive conditions for plasmid replication, cells maintain antibiotic resistance only if the plasmid integrates into the chromosome by homologous recombination between the cloned fragment and the bacterial chromosome. Excision of the integrated plasmid takes place by a second homologous recombination, integrating the desired mutation into the bacterial genome, and could be sometimes selected for antibiotic sensitivity or resistance to the presence of sucrose in the agar [14]. Allison et al. [15] produced recombinant phages by the creation of a recombinant plasmid harbouring the mutagenic template. Homologous recombination takes place between the replicating plasmid bearing the genetic construct and either the integrated prophage, the new replicated phage genome copy or the incoming viral genome. In the last two situations, DNA would have to be in the circular intermediate form. This method avoids the use of a suicide vector and recombinant phages were identified at a very high frequency. Similar approaches were also applied by other authors [8]. The mini-transposon Tn $10 d-b l a$, was used to produce beta-lactamase fusions to phage-encoded, exported proteins [16].

Some methods have been also developed to introduce linear DNA in Gram-positive or Gram-negative bacteria [1719]. In parallel, Datsenko and Wanner [20] proposed a method for inactivating chromosomal genes in E. coli K12 in one step, by recombining a PCR product using the lambda Red system $(\gamma, \beta$, exo $)$. This enhances the recombination of linear DNA in the E. coli chromosome, as it promotes efficient double-strand break repair/ recombination. This method is analogous to that used for many years in yeast [20]. It is a useful method for constructing mutants, avoiding the use of suicide plasmids or the previous generation of plasmids carrying the constructs. Several authors have successfully applied this method for different purposes $[21,22]$.

Some bacterial virulence factors, such as toxins or antibiotic resistance genes, are frequently encoded by bacteriophages. For example, factors encoded by phages have been described in some of the emerging or reemerging pathogens. These include: pyrogenic exotoxin A production in group A streptococci [23]; cholera toxin in Vibrio cholerae [24]; betalactamase genes [25]; and the production of Shiga toxin, the subject of this study and one of the most important virulence factors in Shiga toxin-producing strains of E. coli (STEC). The toxin genes are encoded by the genome of temperate lambdoid bacteriophages or $s t x$-phages [26-28]. The use of the Red recombinase methodology can be applied to introduce marker genes in the prophage genomes, within the non-essential toxin genes, as prophage genes behave like chromosomal genes. Here we present an approach based on the use of the Red recombinase system to construct Shiga toxin-producing bacteriophages carrying antibiotic resistance genes.

\section{Results and Discussion \\ Modification of the Red recombinase methods}

Our first attempts at using the protocol described by Datsenko and Wanner [20] to construct recombinant prophages were unsuccessful. After several trials, we decided to modify the protocol. The modifications 
allowed the use of this methodology with the special characteristics of our strains, which carry inducible Shiga toxin-converting prophages.

The most obvious drawback was the spontaneous activation of the phage's lytic cycle during the process. This affirmation is supported by the isolation of phage DNA from the supernatants of the bacterial cultures without previous induction (data not shown). This increased prophage excision and/or phage release, which significantly reduced the efficacy of recombinant clone formation. Two possible causes of this failure were considered. Possibly, excision of the prophage DNA from bacterial DNA occurred without phage particle formation. In this case, the target gene (stx) where the amplimer must recombine would be lost, thus hindering correct recombination. Alternatively, after excision, phage particles were formed and released from the cells by lysis. In this case, a significant proportion of bacterial cells would be lysed, reducing the number of cells susceptible to transformation. Both of these scenarios would lead to a reduction in the efficacy of obtaining recombinant clones. The first cause could not be checked, but the second one was experimentally confirmed by the moderate reduction of the $\mathrm{OD}_{600}$ observed in the cultures of the lysogens during the process, compared with the $\mathrm{OD}_{600}$ of E. coli $\mathrm{C} 600$ or DH5 $\alpha$ cultures (non-lysogens) used as a control.

The spontaneous induction of the lytic cycle could be due to several causes that would activate the SOS response. For example, the double application of the protocol to prepare electrocompetent cells (firstly to transform plasmid pKD46 and secondly to transform the PCR amplimer) which may activate the stress response in the bacterial cell. In any case, we assayed several modifications of the original protocol to optimize our application. These modifications of each step and the results obtained are described in this section.
Confirmation of the presence of the stx genes after pKD46 vector transformation

We examined the efficacy of the transformation of the helper plasmid pKD46 in the first step of the method, to evaluate the efficacy of our transformation protocol. Vector pBC-SK was used as a control. Vector pKD46 presented a lower transformation efficacy than $\mathrm{pBC}$-SK. The number of transformed colonies was on average 6-10 fold higher with pBC-SK. These results could be due to the fact that pKD46 carries a temperature-sensitive origin of replication and only replicates at $30^{\circ} \mathrm{C}$. Therefore the growth rate of cells transformed with pKD46 is lower than that of cells transformed with $\mathrm{pBC}-\mathrm{SK}$ and grown at $37^{\circ} \mathrm{C}$.

In addition to these expected results, the introduction of the pKD46 vector produced the loss of the $s t x_{2}$ gene in some of the lysogens. This was observed in a high proportion of the analyzed colonies (Table 1). The percentage of gene loss in such lysogens was significantly higher ( $t$-Student, $p<0.05)$ than the percentage of $s t x_{2}$ gene loss in transformed cells after transformation with vector $\mathrm{pBC}$ SK, used as control (Table 1). Only lysogens C600(933W) and C600(A9) did not show any gene loss which could suggest a higher stability of lysogens obtained with strain C600.

Since the $s t x_{2}$ gene was required to continue with the protocol, the presence of the vector and the $s t x_{2}$ gene in the selected clones was confirmed by a double hybridization with the respective stx and Red recombinase probes. Only clones in which the pKD46 and the $s x_{2}$ gene were observed could be used in the next steps to transform the amplimer containing the antibiotic gene.

Other phage sequences, such as the rho independent terminator, the $c I$ gene or the $Q$ gene, which are present in the studied phages, were also absent in colonies lacking the $s t x_{2}$ gene (data not shown). This suggests that excision of the whole prophage DNA from the host cell occurred. However, since this was not the aim of this work, further investigations were not undertaken.

Table I: Transformation efficiency of the E. coli lysogens carrying stx $\mathbf{2}_{2}$-phages

\begin{tabular}{|c|c|c|c|c|}
\hline & \multicolumn{2}{|l|}{ pBC-SK+ } & \multicolumn{2}{|l|}{ pKD46 } \\
\hline & Vector + & $s t x^{+}$ & Vector + & $s t x^{+}$ \\
\hline DH5 $\alpha$ (VTB55) & $99.0^{a}$ & 100.0 & 100 & 6 \\
\hline $\mathrm{DH} 5 \alpha(3 \mid 2)$ & 98.5 & 96.5 & 100 & 1 \\
\hline $\mathrm{DH} 5 \alpha(534)$ & 100.0 & 99.5 & 100 & 80 \\
\hline DH5 $\alpha$ (549) & 97.5 & 100.0 & 100 & 5 \\
\hline DH5 $\alpha$ (557) & 100.0 & 100.0 & 100 & 3 \\
\hline C600(A9) & 99.2 & 100.0 & 100 & 100 \\
\hline C600(933W) & 100.0 & 100.0 & 100 & 100 \\
\hline
\end{tabular}

aPercentage of colonies positive for the presence of each vector performed in parallel in two plates, relative to the total number of colonies grown in plates with the respective antibiotic. Results were obtained by colony hybridization of the colonies present in a plate. 
There is no explanation for the loss of the stx gene in a high percentage of the cells transformed with pKD46. Conditions were the same for all lysogens and some of them did not lose the stx. A possible hypothesis is that the presence of the Red recombinase system could increase the excision of certain prophages from the bacterial genome of some lysogens, without virus formation and without subsequent cell lysis.

\section{Construction of the amplimer}

One of the most important modifications to the protocol involved the construction of the PCR amplimer. In the first set of experiments, we used two primer sets to amplify the resistance marker containing each 36 bp and 40 bp extension sequences (short homologous arms) with homology to the stx genes (Table 2). These shared sequences were expected to be effective with the Red recombinase system. The primers were designed to obtain a Tc amplimer and a $\mathrm{Cm}$ amplimer that could be inserted into the recombinant phages. However, no antibioticresistant transformants of our lysogens were obtained using these primers. Therefore they were excluded from the experimental procedure.

The presence of Tc-resistant transformants was only observed on a few occasions when using the above described primers. However, the Tc cassette was not present inside the $s t x_{2}$ gene but somewhere else in the bacterial chromosome, despite the fact that all the plasmids used as templates of the antibiotic cassettes had conditional replicons to avoid erroneous integrations as suggested in the original protocol. Digestion of the amplimers with DpnI was to reduce this problem did not improve the results. The use of short homology sequences (36-40 bp) for the recombination could possibly be the cause of the wrong recombination events or the lack of recombinations. For this reason, the length of the homology regions where the recombinase can act, was increased. For this purpose a new strategy, based on the 3S-PCR protocol [29] was used to increase the length of the homology region shared by the amplimer and the $s t x_{2}$ gene.

The unusual recombination events are difficult to explain. Conceivably, the presence of the stx lambdoid prophages, some of which could include different recombinase genes, might somehow enhance non-homologous recombination. This would lead to the insertion of the antibiotic resistance cassette in unexpected sites outside of the target gene. In fact, the sequencing of several E. coli genomes has revealed the widespread occurrence of multiple integrases of phage origin [30] with similar sequence homology. These can help to explain our observations, which have also been described by other authors [31].

Table 2: Summary of the diverse conditions used and final protocol

\begin{tabular}{|c|c|c|c|}
\hline Step ${ }^{a}$ & Condition & $\begin{array}{l}\text { Obtention of recombinant } \\
\text { colonies (CFU/ml) }\end{array}$ & Final established condition \\
\hline \multirow[t]{4}{*}{ Construction of the amplimer } & Short homologous arms & No & Long primers \\
\hline & Long homologous arms & Yes & Single PCR reaction for tet \\
\hline & Single PCR reaction & 21 for $T c$ & Three PCR reaction for cat \\
\hline & Three PCR reactions & 19 for $\mathrm{Cm}$ & \\
\hline \multirow[t]{3}{*}{ Amount of amplified DNA to be transformed } & $0.1 \mu \mathrm{g}$ & 0 & $0.5 \mu \mathrm{g}$ \\
\hline & $0.25 \mu \mathrm{g}$ & 0 & \\
\hline & $0.5 \mu \mathrm{g}$ & $21 \mathrm{Tc}, 19 \mathrm{Cm}$ & \\
\hline \multirow{4}{*}{$\begin{array}{l}\text { Culture volume used for preparation of } \\
\text { electrocompetent cells }\end{array}$} & $5 \mathrm{ml}\left(2 \times 10^{9} \mathrm{CFU} / \mathrm{ml}\right)$ & 0 & $50 \mathrm{ml}\left(5.10^{10} \mathrm{CFU} / \mathrm{ml}\right)$ \\
\hline & $10 \mathrm{ml}\left(10^{10} \mathrm{CFU} / \mathrm{ml}\right)$ & 0 & \\
\hline & $25 \mathrm{ml}\left(2.5 \times 10^{10} \mathrm{CFU} / \mathrm{ml}\right)$ & $\mathrm{I} \mathrm{Tc}, 0 \mathrm{Cm}$ & \\
\hline & $50 \mathrm{ml}\left(5 \times 10^{10} \mathrm{CFU} / \mathrm{ml}\right)$ & $9 \mathrm{Tc}, 8 \mathrm{Cm}$ & \\
\hline \multirow[t]{2}{*}{ Temperature after electroporation } & $30^{\circ} \mathrm{C}$ & $2 \mathrm{Tc}, \mathrm{I} \mathrm{Cm}$ & $37^{\circ} \mathrm{C}$ \\
\hline & $37^{\circ} \mathrm{C}$ & $15 \mathrm{Tc}, 9 \mathrm{Cm}$ & \\
\hline \multirow[t]{3}{*}{ Arabinose concentration media } & I mM & $18 \mathrm{Tc}, 9 \mathrm{Cm}$ & $0.1 \mathrm{M}$ \\
\hline & $10 \mathrm{mM}$ & $10 \mathrm{Tc}, 8 \mathrm{Cm}$ & \\
\hline & $0.1 \mathrm{M}$ & $20 \mathrm{Tc}, \mathrm{II} \mathrm{Cm}$ & \\
\hline \multirow[t]{2}{*}{ Concentration of antibiotic in plating media } & Tc $20 \mu \mathrm{g} / \mathrm{ml}, \mathrm{Cm} 20 \mu \mathrm{g} / \mathrm{ml}$ & $\mathrm{I} \mathrm{Tc}, 0 \mathrm{Cm}$ & Tc $5 \mu \mathrm{g} / \mathrm{ml}, \mathrm{Cm} 5 \mu \mathrm{g} / \mathrm{ml}$ \\
\hline & Tc $5 \mu \mathrm{g} / \mathrm{ml}, \mathrm{Cm} 5 \mu \mathrm{g} / \mathrm{ml}$ & $21 \mathrm{Tc}, 19 \mathrm{Cm}$ & \\
\hline
\end{tabular}

a Each set of experiments was performed independently of the other tests with one phage for each antibiotic.

b Phage used for tet was ØVTB55; Phage used for cat was ØA9. 
To increase the length of the $s t x_{2}$ homologous region upstream and downstream of the antibiotic resistance cassette, new amplimers were created by using overlapping regions between three different fragments: the 3' fragment, containing the $s t x_{2}$ homology; the antibiotic resistance cassette; and the 5 ' cassette, which also contains the $s t x_{2}$ homology (Fig 1). Some amplimers, such as the one containing tet, were directly obtained using the three fragments simultaneously as templates in the same PCR reaction. For cat, the 3 '-fragment joined to the antibiotic cassette was amplified in a first PCR reaction and the antibiotic cassette joined to the 5 '-fragment in a second one. Then both fragments were used together to obtain the complete amplimer in a third PCR reaction.

The use of longer homologous regions (280 bp at each side) in the amplimer carrying the antibiotic cassettes definitely solved the problem of false recombinants (Table 2 ). In the above mentioned application (29), the rational for the use of longer regions of homology was to increase the probability of the double event of recombination that lead to the desired allelic exchange in non-E. coli K-12 bacteria. This was explained by the authors since the lambdared functions became less efficient in blocking DNA degradation in bacteria that are distantly related to E. coli. Therefore, longer regions of homology increased the efficiency. Although our application was performed using an E. coli K-12 derivative, strain DH5 $\alpha$, the same strategy of long arms seems to be suitable for our purposes.

The amount of the amplimer to be transformed was also evaluated and finally established at $0.5 \mu \mathrm{g}$ of amplified DNA (Table 2). From 10-100 ng of amplified DNA were established in the original protocol [20]. However, in our hands and using an amplimer longer than the one described in the original protocol, higher concentrations were necessary.

\section{Transformation of the amplimer}

Initially, we used $5 \mathrm{ml} \mathrm{SOB}$ cultures with ampicillin and $10 \mathrm{mM}$ of L-arabinose as described by Datsenko and Wanner [20]. However, no recombinant clones were obtained. In successive attempts, lysogenic cells (pKD46 $\left.6^{+}, s t x_{2}{ }^{+}\right)$in culture volumes of 10,25 and finally $50 \mathrm{ml}$ were used to prepare electrocompetent cells (Table 2). Electrocompetent cells prepared from $50 \mathrm{ml}$ of culture were finally used to obtain recombinant clones. This problem did not apply in the approach described by Datsenko and Wanner [20], but in our approach it was necessary to obtain few recombinant colonies. This confirmed our hypothesis that in our cultures the initial number of cells was probably reduced by the activation of phage lysis during the protocol for preparation of electrocompetent cells or by the presence of antibiotic in the culture media. Therefore the minimal numbers of cells in the initial culture necessary to obtain a single recombinant colony was of $2.5 \times 10^{10}$ $\mathrm{CFU} / \mathrm{ml}$.

Different concentrations of L-arabinose were also tested. In optimal conditions, no significant differences were observed in our experiments when using different amounts of arabinose. We assayed $1 \mathrm{mM}$ (indicated in the original protocol), $10 \mathrm{mM}$ and $0.1 \mathrm{M}$ of L-arabinose. Recombinant clones were obtained in all cases. However, the highest number of clones was obtained with $0.1 \mathrm{M}$ of arabinose (Table 2). These results indicate that all of the concentrations tested were inside the range needed to generate the expression of the $\gamma \beta$ exo gene system in a proportion of the transformed cells. This is required in a system that is dependent on arabinose concentrations and that has been described as "all-or-none induction of $\mathrm{P}_{\mathrm{BAD}}$ " [32].

After transformation of the amplimer, the cells were recovered in $1 \mathrm{ml}$ of SOC medium and incubated for 1 to 3 hours at $37^{\circ} \mathrm{C}$ (as suggested in the original method) or $30^{\circ} \mathrm{C}$ before plating. Three hours of incubation were required to obtain recombinants. Although pKD46 is supposed to be a temperature sensitive vector and cannot replicate above $30^{\circ} \mathrm{C}$, the proteins encoded by the vector still can be active inside the competent cells enhancing recombination. There were no great differences in the number of clones obtained from incubation at different temperatures (Table 2) although more colonies were obtained at $37^{\circ} \mathrm{C}$. In fact, incubation at $37^{\circ} \mathrm{C}$ increased the growth rate, producing more cells.

\section{Plating media}

LB agar plates containing Tc and $\mathrm{Cm}$ were used as selective media. Datsenko and Wanner [20] proposed the use of 25 $\mu \mathrm{g} / \mathrm{ml}$ for $\mathrm{Cm}$ and $\mathrm{Km}$. Initially, we tested concentrations of $20 \mu \mathrm{g} / \mathrm{ml} \mathrm{Tc}$ or $20 \mu \mathrm{g} / \mathrm{ml} \mathrm{Cm}$ for the recovery of recombinants. However, no recombinants were observed on $\mathrm{Cm}$ or Tc plates (Table 2). Positive results were obtained when using lower antibiotic concentrations in the selective media. Therefore, LB plates containing $5 \mu \mathrm{g} / \mathrm{ml}$ Tc or $5 \mu \mathrm{g} /$ $\mathrm{ml} \mathrm{Cm}$ were finally used for the recovery of recombinants. Once plated, 24 hours of incubation were enough to visualize colonies. The colonies were then transferred to new LB agar plates with higher antibiotic concentrations (Tc: $20 \mu \mathrm{g} / \mathrm{ml}$ and $\mathrm{Cm}: 20 \mu \mathrm{g} / \mathrm{ml}$ respectively). Thus lysogens carrying recombinant phages did not grow immediately in the expected antibiotic concentrations, possibly be because bacterial cells need to recover after the process, and were damaged when directly submitted to high antibiotic concentrations.

Loss of the vector was achieved after successive subcultures and incubation at $43^{\circ} \mathrm{C}$ without ampicillin selection, as previously described [20]. The loss of the plasmid 


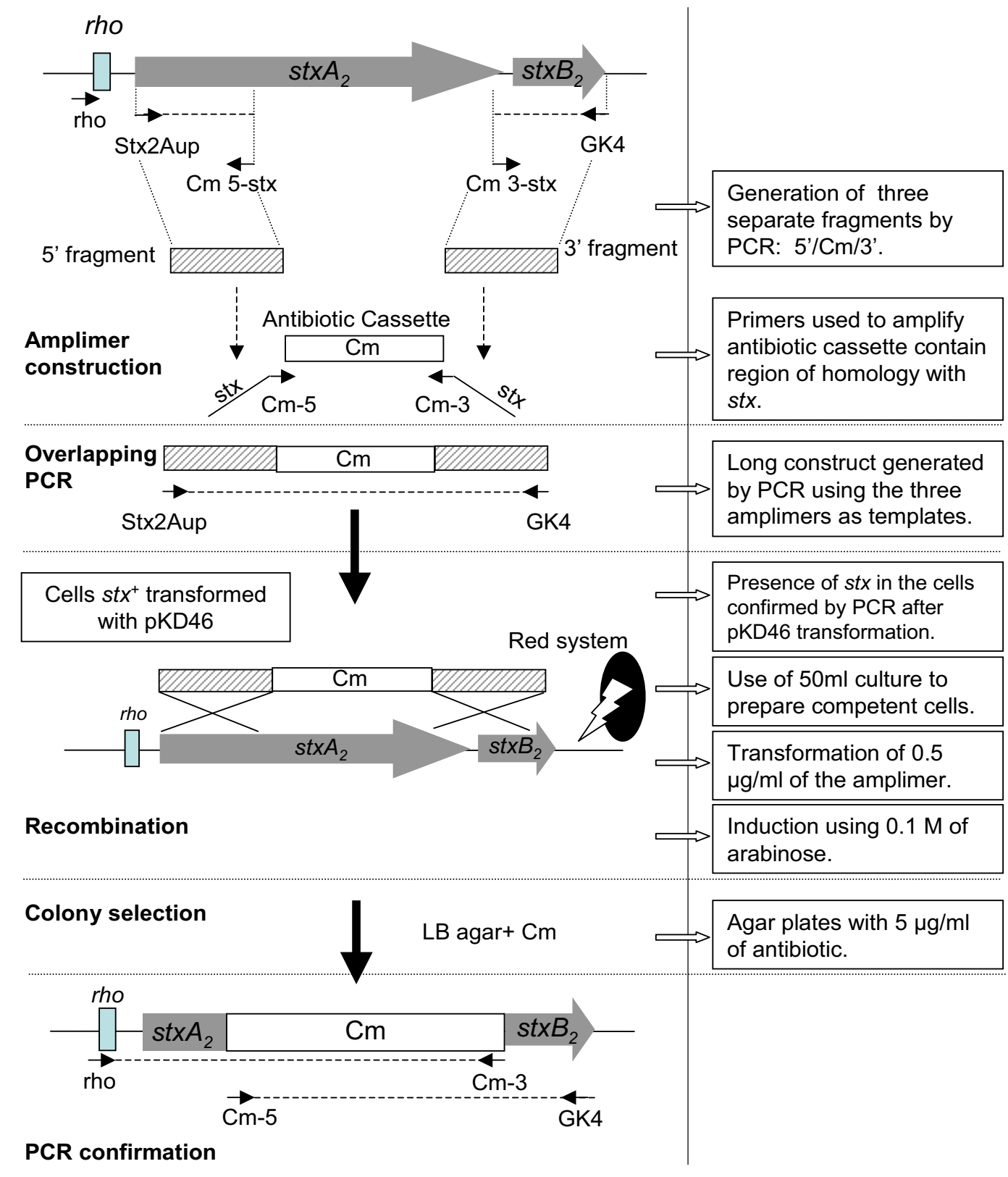

Figure I

Scheme of the protocol used to construct the amplimers containing the stx gene substituted by the antibiotic resistance gene. The figure shows the protocol used for the cat gene as an example. 
was confirmed by observing the absence of the PCR amplimer, using the primers described in Table 1 for vector pKD46.

Table 2 summarizes all the variations assayed in our protocol; the number of recombinant clones obtained with two of the bacteriophages using the different modifications; and the final conditions that were established.

\section{Recombinant phages}

The tet and cat genes were introduced in the stx $x_{2}$ gene of prophages: ØА9, ØА312, ØА534, ØА549, ØА557, ØVTB55 and 933W. The genes were placed at position 251 bp of the $s t x_{2}-A$ subunit and 264 bp upstream of the end of the $s t x_{2}-B$ subunit. The identification and characterisation of the respective gene in each recombinant prophage was achieved by PCR and sequencing.

The induction of $s t x_{2}$-phages from the six recombinant lysogens had slightly different kinetics than the original lysogens. Nevertheless, all recombinant lysogens conserved their lytic capacity after incorporating the antibiotic resistance gene. As previously described [33,34], plaques produced by st $x$-phage are usually poorly visible or turbid on the top agar layer. Therefore, confirmation of the presence of infective recombinant phages was achieved by plaque blot hybridization with specific cat or tet probes (data not shown).

The antibiotic resistance cassette appears to remain stable within the phage genome, as observed after four steps of subculture without antibiotic selection. However the long-term stability of the marker gene in the phage genome without antibiotic selection remains to be elucidated.

\section{Recombinant transductants}

To evaluate the capacity of the recombinant phages to infect and convert new E. coli strains, suspensions of the recombinant phages were prepared. Transduction of $E$. coli DH5 $\alpha$ and E. coli $\mathrm{C} 600$ was performed. All phages produced new transductants, which conferred resistance to the appropriate antibiotic on DH5 $\alpha$ or C600. Presence of the recombinant prophages in the host strain was confirmed by PCR and plaque hybridization analysis (Figure 2).

Some other authors have produced recombinant stxphages $[9,15,16]$ for different purposes. Schmidt et al. [9] used phage $\$ 3538$ to infect and lysogenize enteric Escherichia coli strains and to develop infectious progeny from such lysogenized strains. Allison et al., [15] used recombinant phages to show the first reported observation of the simultaneous infection of a single host with two genetically identical Stx phages. Acheson et al., [16] generated a recombinant Shiga toxin 1-converting phage $\mathrm{H}-19 \mathrm{~B}$ to facilitate the study of intestinal transmission of st $x_{1}$-phages.

In the present work we have generated different recombinant phages with two antibiotic resistance genes to use them for different purposes. The use of these phages will allow analyse transduction in different matrices, as food or water samples. It would also be interesting to evaluate the phage induction and the transduction after different processes applied for food or water treatments, such as high temperature or high hydrostatic pressure (HHP), which has been reported as a method that can generate an increase in the induction of the lytic cycle of certain stxphages [35].

The recombinant phages would be also useful tools to evaluate the ability of st $x$-phages to generate double lysogens and to evaluate whether the double lysogeny is really favoured in STEC, as some observations done in water environments or in strains isolated from humans and animals would suggest $[15,33,36,37]$.

\section{Conclusion}

The Red recombinase system was utilised and adapted for the purpose of disrupting chromosomal genes in E. coli K12. Although it is a very simple and efficient system, once used in a chromosomal environment where some other phage-related sequences are present, several unexpected events were observed making it difficult to obtain recombinants. Additionally, the spontaneous release and loss of stx genes occurring in some strains carrying stx-prophages, as already described [38] decreases this method's efficacy.

Remarkably, this problem does not affect all stx $x_{2}$-encoding prophages, since some of them could be manipulated using the original protocol of Datsenko and Wanner [20]. Indeed, the substitution of the stx 2 genes of $\phi 330$, a phage isolated from a Belgian E. coli O157:H7 isolate, by the chloramphenicol resistance cassette amplified from pKD3 was achieved in this way (S. Acosta, N. Buys and J.P. Hernalsteens, unpublished results).

The modification of the Red Recombinase system reported in the present study offer some solutions for constructing recombinant bacteriophages. This study focused on the construction of recombinant stx-phages carrying antibiotic resistance genes within the stx operon. However, the approach could also be considered to produce recombinant phages carrying some other marker genes such as: the $\beta$-galactosidase gene, lac $Z$; the bacterial luciferase gene, luxAB; or the green fluorescent protein gene, $g f p$ [8]. In addition, this methodology could be useful for prophages infecting other enterobacteria, since the method has been applied to Salmonella [21]; Shigella [39]; 
Serratia [40]; and Yersinia [41], which also carry prophages encoding virulence genes [42-44].

\section{Methods}

\section{Bacteriophages, bacterial strains, plasmids, and growth} conditions

The bacteriophages ØA9, ØА312, ØА534, ØА549, ØA557, ØVTB55 used in the experiments were induced from selected STEC strains described elsewhere [36] and consisting of serotypes O157:H7 and O2:H27.

E. coli laboratory strains DH5 $\alpha$ and C600 were used as host strains in some of the experiments described below. The aforementioned bacteriophages were introduced in these receptor strains as mentioned elsewhere [36] to generate the lysogens: C600(A9), DH5 $\alpha(534)$, DH5 $\alpha(557)$, DH5 $\alpha$ (VTB55), DH5 $\alpha(312)$ and DH5 $\alpha(549)$.
Bacteriophage 933W [26] was induced from E. coli C600(933W), as described below, and used as a reference stx-bacteriophage.

Bacterial strains were grown in Luria-Bertani (LB) broth and on LB agar. The LB medium was supplemented with: ampicillin (Ap) $(100 \mu \mathrm{g} / \mathrm{ml})$; chloramphenicol (Cm) (5 $\mu \mathrm{g} / \mathrm{ml})$; and tetracycline (Tc) $(5 \mu \mathrm{g} / \mathrm{ml})$, when needed. SOB and SOC media [45] were used to prepare electrocompetent cells and for recovery after transformation. TSB medium supplemented with $5 \mathrm{mM} \mathrm{CaCl}_{2}$ was used for the preparation of phage lysates

\section{Plasmids}

Plasmid pKD46 (Genbank AY048746) was used for the expression of Red recombinase [20]. Plasmid pACYC184 (Genbank X06403) [46] was used to obtain the tetracycline resistance gene (tet). Plasmid pKD3 (Genbank AY048742) [20] was used to obtain the chloramphenicol acetyl transferase gene (cat), which confers resistance to

A

\begin{tabular}{lcccc}
\hline Phage & \multicolumn{2}{c}{ Cm } & \multicolumn{2}{c}{ Tc } \\
\cline { 2 - 5 } & DH5 $\alpha$ & C600 & DH5 $\alpha$ & C600 \\
\hline ØVTB55 & $9.6 .10^{5}$ & $1.8 .10^{6}$ & $9.0 .10^{6}$ & $4.3 .10^{6}$ \\
Ø312 & $6.0 .10^{1}$ & $7.0 .10^{3}$ & $6.0 .10^{0}$ & $1.3 .10^{1}$ \\
$\varnothing \mathbf{5 3 4}$ & $1.3 .10^{7}$ & $6.2 .10^{7}$ & $1.0 .10^{0}$ & $1.5 .10^{1}$ \\
$\varnothing 549$ & $1.4 .10^{1}$ & $2.5 .10^{1}$ & $1.0 .10^{1}$ & $2.1 .10^{1}$ \\
$\varnothing \mathbf{5 5 7}$ & $2.7 .10^{2}$ & $3.7 .10^{3}$ & $3.7 .10^{2}$ & $7.2 .10^{3}$ \\
$\varnothing \mathbf{A 9}$ & $1.0 .10^{8}$ & $7.2 .10^{6}$ & $5.7 .10^{6}$ & $6.3 .10^{6}$ \\
$\varnothing \mathbf{9 3 3 W}$ & $7.2 .10^{6}$ & $3.3 .10^{7}$ & $1.3 .10^{8}$ & $2.1 .10^{8}$ \\
\hline
\end{tabular}

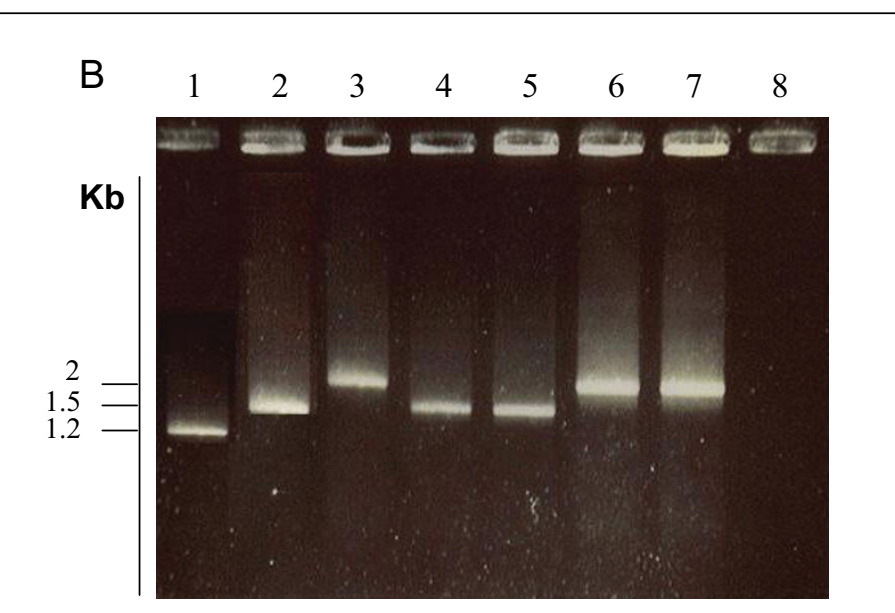

C

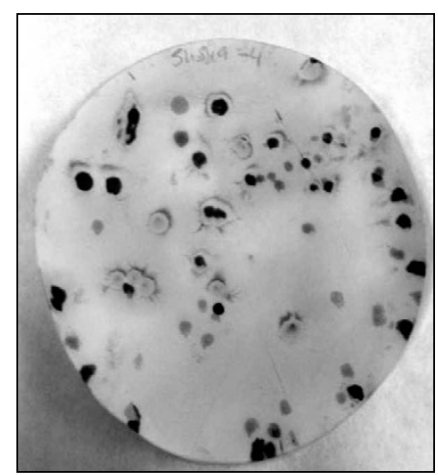

Figure 2

A) Number of transductants (CFU/ml) obtained in E. coli DH5 $\alpha$ and E. coli $\mathrm{C} 600$ with each recombinant phage carrying cat or tet antibiotic resistance genes. B) PCR products of each recombinant colony carrying a stx-prophage with the respective antibiotic resistance cassette. I: stx gene control, 2: cat control, 3: tet control, 4-5: E. coli DH5 $\alpha$ and E. coli C600 lysogens with stxphages::cat. 6-7: E. coli DH5 $\alpha$ and E. coli C600 lysogens with stx-phages::tet-. 8 negative PCR control; C) As an example, colony blot of $\mathrm{DH} 5 \alpha(\varnothing 557::$ tet) hybridized with the specific probe for the tet gene. 
Table 3: Oligonucleotides used in this study

\begin{tabular}{|c|c|c|c|c|}
\hline Primers & Sequence & Gene region & Size (bp) & Reference \\
\hline UP 378 & GCGTTTTGACCATCTTCGT & & & \\
\hline LP 378 & ACAGGAGCAGTTTCAGACAG & 378 bp fragment $s t x_{2}-A$ & 378 & 49 \\
\hline S2Aup & ATGAAGTGTATATTATTTA & Binds stx2-A subunit at initial codon & - & 7 \\
\hline GK4 & TCAGTCATTATTAAACTG & Binds stx2-B subunit at final codon & - & 50 \\
\hline $\mathrm{Cm} 5$ & TGTGTAGGCTGGAGCTGCTTC & & & \\
\hline $\mathrm{Cm}-3$ & CATATGAATATCCTCCTTAG & cat gene & 1015 & This study \\
\hline Cm 5-stx & GAAGCAGCTCCAGCCTACACAACGAAGATGGTCAAAACGCG & & & \\
\hline Cm3-stx & CTAAGGAGGATATTCATATGAGGAGTTAAGTATGAAGAAG & $\begin{array}{l}\text { Used for construction of the } 5^{\prime} \text { fragment } \\
\text { and } 3^{\prime} \text { fragment of the cat gene }\end{array}$ & - & This study \\
\hline Tc 5 & TCAGCCCCATACGATATAAG & & & \\
\hline Tc-3 & TGGAGTGGTGAATCCGTTAG & tet gene & 1180 & This study \\
\hline Tc 5-stx & CTTATATCGTATGGGGCTGAACGAAGATGGTCAAAACGCG & & & \\
\hline Tc3-stx & CTAACGGATTCACCACTCCAAGGAGTTAAGTATGAAGAAG & $\begin{array}{l}\text { Used for construction of the } 5^{\prime} \text { fragment } \\
\text { and } 3^{\prime} \text { fragment of the tet gene }\end{array}$ & - & This study \\
\hline Tc-int & TGTCGGAATGGACGATAT & Bind Tc cassette at $100 \mathrm{bp}$ of 5 of tet & - & This study \\
\hline Rho & ATATCTGCGCCGGGTCTG & $\begin{array}{l}\text { Binds rho independent terminator } \\
\text { sequence upstream } s t x_{2}-A \text { subunit }\end{array}$ & - & This study \\
\hline RR46 LP & GAGCTCTAAGGAGGTTAT & & & \\
\hline RR46-UP & GTGCAGTACTCATTCGTT & Red recombinase gene in pKD46 vector & 457 & This study \\
\hline $\mathrm{pBC}$ KS & TCGAGGTCGACGGTATC & & & \\
\hline MI3 rev & GGAAACAGCTATGACCATG & Detection of $\mathrm{pBC}-\mathrm{SK}+$ vector & 158 & Stratagene \\
\hline
\end{tabular}

chloramphenicol. Plasmid pBC-SK+ (Stratagene Inc. Amsterdam, the Netherlands) was used as a control for the transformation. All vectors were purified using the Qiagen Plasmid Midi purification kit (Qiagen Inc., Valencia, USA).

\section{PCR techniques}

PCR reactions were performed using a GeneAmp PCR system 2400 (Perkin-Elmer, PE Applied Biosystems, Barcelona, Spain.). One $\mu \mathrm{l}$ of cellular suspension obtained from three-four colonies was used for the PCR amplification. The oligonucleotides used in this study are described in Table 3.

Construction of the amplimers containing tet and cat genes, inserted in the $s_{2} x_{2}$ gene, was performed as follows. The primer pairs Tc5'-Tc3'and $\mathrm{Cm} 5-\mathrm{Cm} 3$ (Table 3) were used for the amplification of the tet and cat genes respectively, with an annealing temperature of $54^{\circ} \mathrm{C}$ and elongation time of $45 \mathrm{~s}$. Primer pairs amplified from the $s t x \mathrm{~A}_{2}$ subunit initial codon to the 5 ' region of each resistance cassette ( 5 ' fragment) and from the 3 ' region of each resistance cassette to the final codon of the $s t x B_{2}$ subunit ( $3^{\prime}$ fragment) (Fig 1). The conditions used for all primer combinations were an annealing temperature of $41^{\circ} \mathrm{C}$ and elongation time of $45 \mathrm{~s}$. The amplimers obtained were S2Aup/Tc5-stx (290 bp), S2Aup/Cm5-stx (291 bp) and GK4/Tc3-stx (281 bp) and GK4/Cm3-stx (281 bp).

Amplimers of the 5' fragment, the respective resistance gene and the 3 ' fragment for each resistance gene were annealed at their overlapping region (underlined letters in Table 3). They were then amplified by PCR as a single fragment with the external primers S2Aup and GK4 with an annealing temperature of $41^{\circ} \mathrm{C}$ and an elongation time of $2 \mathrm{~min}$. The fusion product was amplified again using primer pair S2Aup/GK4. It was then excised from the gel and purified using the Qiaquick Gel Extraction Kit (Qiagen Inc., Valencia, USA). The final product was used for the transformation in the lysogens.

\section{Preparation of digoxigenin-labelled stxA $\mathrm{A}_{2}$, tc and cat specific gene probes}

A DNA fragment of the $s t x_{2} A$ gene obtained with primers UP378/LP378, the tet gene and the cat gene, resulting from amplification with the respective primers (Table 3 ), were labeled with digoxigenin and used as probes. The probes were labeled by incorporating digoxigenin-11deoxy-uridine-triphosphate (Roche Diagnostics, Barcelona, Spain) during PCR, as described in Muniesa et al., [36].

\section{Hybridization techniques}

Plaque blot was performed using Nylon- $\mathrm{N}+$ membranes (Hybond N+, Amersham Pharmacia Biotech, Spain) [47].

Colony hybridization was performed as previously described [37]. The membranes were washed in a solution consisting of $1 \%$ SDS, $2 \times$ SSC for five min at $50^{\circ} \mathrm{C}$. They were then washed in $0.1 \%$ SDS, $2 \times$ SSC for $5 \mathrm{~min}$ at room temperature and finally in $2 \times$ SSC for $5 \mathrm{~min}$ at room temperature. 
Membranes were pre-hybridized with standard prehybridization solution at $68^{\circ} \mathrm{C}$ for 2 hours. Stringent hybridization was achieved with the DIG DNA Labelling and Detection Kit (Roche Diagnostics, Barcelona, Spain), according to the manufacturer's instructions. The DIGlabeled probes were prepared as described above.

\section{Electroporation}

Electroporation-competent cells were prepared from 10$50 \mathrm{ml}$ of cultures in SOB medium and concentrated by centrifugation at $3000 \times \mathrm{g}$ for $5 \mathrm{~min}$. They were then washed in $2 \mathrm{ml}$ of ice-cold double distilled water. After four washing steps, the cells were suspended in 15-100 $\mu \mathrm{l}$ of ice-cold double-distilled water. The cells were mixed with the corresponding amount of DNA (plasmid or PCRamplified, see results) in an ice-cold microcentrifuge tube and transferred to a $0.2 \mathrm{~cm}$ electroporation cuvette (BioRad, Inc.). The cells were electroporated at $2.5 \mathrm{kV}$ with 25 $\mathrm{F}$ and $200 \mathrm{ohm}$ resistance. Immediately after electroporation, $1 \mathrm{ml}$ of SOC medium [47] was added to the cuvette. The cells were transferred to a 17 by $100 \mathrm{~mm}$ polypropylene tube and recovered in SOC medium for 1-4 hours at either $30^{\circ} \mathrm{C}$ (for temperature-sensitive plasmids) or $37^{\circ} \mathrm{C}$, without shaking. Cells were concentrated ten-fold from a $1 \mathrm{ml}$ culture before plating on selective media.

\section{Recombinant phage construction}

A protocol modified from the one-step inactivation method using the Red recombinase system, as proposed by Datsenko and Wanner [20], was performed to obtain recombinant phages. Antibiotic resistance cassettes were inserted inside the truncated $s t x_{2}$ gene of each phage to obtain recombinant phages carrying the resistance markers. For this purpose, plasmid pKD46 encoding the Red recombinase was transformed by electroporation, as described above. This was performed in electrocompetent cells prepared from $5 \mathrm{ml}$ of the culture (approximately 5 $\times 10^{9} \mathrm{CFU} / \mathrm{ml}$ ) of lysogens: C600(A9), DH5 $\alpha(534)$, DH5 $\alpha(557)$, DH5 $\alpha(V T B 55)$, DH5 $\alpha(312)$, DH5 $\alpha(549)$ and $\mathrm{C} 600(933 \mathrm{~W})$. Transformation of the vector was confirmed by PCR, using the primer pair RR46up/lp. In a second step, the transformation of $30 \mu \mathrm{l}$ of each PCR amplimer (corresponding to 0.1-0.5 $\mu \mathrm{g}$ of amplified DNA) containing the $s t x_{2}$ gene, truncated by insertion of the respective resistance gene and prepared as described above (see PCR techniques), was performed in electrocompetent cells. These cells were prepared from $50 \mathrm{ml}$ cultures (approximately $5 \times 10^{10} \mathrm{CFU} / \mathrm{ml}$ ) of each lysogen containing the pKD46 plasmid, grown at $30^{\circ} \mathrm{C}$ in SOB medium with ampicillin and $0.1 \mathrm{M}$ of L-arabinose to an $\mathrm{OD}_{600}$ of 0.6. After recovery in SOC medium and incubation for 4 hours, recombinant clones were selected on medium containing the appropriate antibiotic. Presumptive colonies were confirmed by PCR, using the rho primer and the respective primer for each antibiotic cassette.
Cycling times and temperatures were according to the properties of the primer pairs. Positive clones were also further confirmed by sequencing.

\section{Sequencing of the stx 2 gene, cat gene and tet gene encoded by temperate phages}

PCR amplimers of the stx gene containing each antibiotic resistance gene and PCR amplimers obtained to characterise recombinant phages were sequenced. The oligonucleotides used for sequencing are described in Table 3.

Sequencing was performed with the ABI PRISM Big Dye III v.1 Terminator cycle Sequencing Ready reaction Kit (Perkin Elmer, Applied Biosystems, Spain) in an ABI PRISM 3700 DNA Analyzer (Perkin Elmer, Applied Biosystems, Spain), according to the manufacturer's instructions. All sequencing was performed in duplicate.

Nucleotide sequence analysis and searches for homologous DNA sequences in the EMBL and Genbank databases were performed with the GCG Wisconsin Package Version 10.2, Genetics Computer Group, Madison, Wisc. BLAST analyses were carried out with the tools available on the web [48].

\section{Isolation of temperate bacteriophages and preparation of phage lysates}

Lysogens were grown from single colonies in TSB medium supplemented with $5 \mathrm{mM} \mathrm{CaCl}_{2}$ at $37^{\circ} \mathrm{C}$ to the exponential growth phase. Growth was measured with a spectrophotometer (Spectronic 501, Milton Roy. Belgium). At $\mathrm{OD}_{600}=0.5$, Mitomycin $\mathrm{C}$ was added to the cultures to a final concentration of $0.5 \mu \mathrm{g} / \mathrm{ml}$. Cultures were then further incubated overnight. The induced cultures were centrifuged at $10,000 \times g$ for $10 \mathrm{~min}$ and the supernatants were filtered through low protein-binding $0.22-\mu \mathrm{m}$-poresize membrane filters (Millex-GP, Millipore, Bedford, MA).

\section{Bacteriophage transduction}

To evaluate the transduction capacity of the recombinant phages, they were used to convert E. coli DH5 $\alpha$ and/or C600 as previously described [9]. Antibiotic resistant colonies were tested by colony blot and confirmed by PCR amplification of the truncated $s t x_{2}$ gene containing the antibiotic marker.

\section{Abbreviations}

Ap, ampicillin; cat, chloramphenicol acetyltransferase; $\mathrm{Cm}$, chloramphenicol; tet, tetracycline resistance gene; Tc, tetracycline;

\section{Authors' contributions}

SA performed experiments of hybridization. J-PH introduced the Red system method, supplied the plasmids and 
the strains. JJ supplied the host strains, generated Fig 1 and 2 and provided supervision. RSM performed the rest of the experiments. MM designed the oligonucleotides provided supervision and wrote the paper.

\section{Acknowledgements}

This study was supported by the Generalitat de Catalunya (2005SGR00592) and for the Ministerio de Educación y Ciencia. Dr. M. Muniesa is a researcher of the "Ramon y Cajal" program of the Spanish government. R. Serra is a recipient of a grant of the Ministerio de Educación y Ciencia (AP2003-397I).

\section{References}

I. Canchaya C, Fournous G, Chibani-Chennoufi S, Dillmann ML, Brussow $\mathrm{H}$ : Phage as agents of lateral gene transfer. Curr Opin Microbiol 2003, 6:417-424.

2. Casjens S: Prophages and bacterial genomics: what have we learned so far? Mol Microbiol 2003, 49:277-300.

3. Smith GR: Homologous recombination in procaryotes. Microbiol Rev 1988, 52:1-28.

4. Lederberg E: Lysogenicity in E. coli K-12. Genetics 195I, 36:560.

5. Ohnishi M, Kurokawa K, Hayashi T: Diversification of Escherichia coli genomes: are bacteriophages the major contributors? Trends Microbiol 200I, 9:48I-485.

6. Banks DJ, Lei B, Musser JM: Prophage induction and expression of prophage-encoded virulence factors in group A Streptococcus serotype M3 strain MGAS3I5. Infect Immun 2003, 71:7079-7086.

7. Muniesa M, de Simon M, Prats G, Ferrer D, Pañella H, Jofre J: Shiga toxin 2-converting bacteriophages associated with clonal turnover in E. coli O 157:H7 strains of human origin isolated from a single outbreak. Infect Immun 2003, $71: 4554-4562$.

8. Oda M, Morita M, Unno H, Tanji Y: Rapid detection of Escherichia coli $0157: \mathrm{H7}$ by using green fluorescent protein-labeled PPOI bacteriophage. Appl Environ Microbiol 2004, 70:527-34.

9. Schmidt $H$, Bielaszewska $M$, Karch $H$ : Transduction of enteric Escherichia coli isolates with a derivative of Shiga-toxin 2encoding bacteriophage $\phi 3538$ isolated from E. coli O I 57: $\mathrm{H7}$. Appl Environ Microbiol 1999, 65:3855-386I.

10. Gutterson NI, Koshland DE: Replacement and amplification of bacterial genes with sequences altered in vitro. Proc Natl Acad Sci USA I 983, 80:4894-4898.

11. Hamilton CM, Aldea M, Washburn BK, Babitzke P, Kushner SR: New method for generating deletions and gene replacements in Escherichia coli. J Bacteriol 1989, 171:4617-4622.

12. Slater S, Maurer R: Simple phage-based system for generating allele replacements in Escherichia coli. I Bacteriol 1993, 175:4260-4262.

13. Biswas I, Gruss A, Ehrlich SD, Maguin E: High-efficiency gene inactivation and replacement system for gram-positive bacteria. J Bacteriol 1993, 175:3628-3635.

14. Link AJ, Phillips D, Church GM: Methods for generating precise deletions and insertions in the genome of wild-type Escherichia coli: application to open reading frame characterization. I Bacteriol 1997, I 79:6228-6237.

15. Allison HE, Sergeant MJ, James CE, Saunders JR, Smith DL, Sharp RJ, Marks TS, McCarthy AJ: Immunity profiles of wild-type and recombinant shiga-like toxin-encoding bacteriophages and characterization of novel double lysogens. Infect Immun 2003, 71:3409-34I8

16. Acheson DWK, Reidl J, Zhang X, Keusch GT, Mekalanos J, Waldor $M$ : In vivo transduction with Shiga toxin I-encoding phage. Infect Immun 1998, 66:4496-4498.

17. Simon D, Ferretti J]: Electrotransformation of Streptococcus pyogenes with plasmid and linear DNA. FEMS Microbiol Lett 1991, 66:219-224.

18. Dabert P, Smith GR: Gene replacement with linear DNA fragments in wild-type Escherichia coli: enhancement by Chi sites. Genetics 1997, 145:877-889.

19. Russell CB, Thaler DS, Dahlquist FW: Chromosomal transformation of Escherichia coli recD strains with linearized plasmids. J Bacteriol 1989, 171:2609-2613.
20. Datsenko KA, Wanner BL: One-step inactivation of chromosomal genes in Escherichia coli K-I 2 using PCR products. Proc Natl Acad Sci USA 2000, 97:6640-6645.

21. Husseiny MI, Hensel M: Rapid method for the construction of Salmonella enterica serovar Typhimurium vaccine carrier strains. Infect Immun 2005, 73:1598-1605.

22. Poteete AR: What makes the bacteriophage lambda Red system useful for genetic engineering: Molecular mechanism and biological function. FEMS Microbiol Lett 200I, 201 :9-14.

23. Johnson LP, Tomai MA, Schlievert PM: Bacteriophage involvement in group A streptococcal pyrogenic exotoxin A production. I Bacteriol 1986, 166:623-627.

24. Waldor MK, Mekalanos Jj: Lysogenic conversion by a filamentous phage encoding cholera toxin. Science 1996, 272:1910-1914

25. Muniesa M, Garcia A, Miro E, Mirelis B, Prats G, Jofre J, Navarro F: Bacteriophages and diffusion of beta-lactamase genes. Emerg Infect Dis 2004, 10: I I34- I 37.

26. O'Brien AD, Newland JW, Miller SF, Holmes RK, Smith HW, Formal $S B$ : Shiga-like toxin-converting phages from $E$. coli strains that cause hemorrhagic colitis or infantile diarrhea. Science 1984, 226:694-696

27. Scotland SM, Smith HR, Willshaw GA, Rowe B: Verocytotoxin production in strain of Escherichia coli is determined by genes carried on bacteriophage. Lancet 1983, ii:216.

28. Herold $\mathrm{S}$, Karch $\mathrm{H}$, Schmidt $\mathrm{H}$ : Shiga toxin-encoding bacteriophages - genomes in motion. Int J Med Microbiol 2004, 294: $115-121$.

29. Lambda red-mediated gene manipulation in gram-negative bacteria [http://www.pasteur.fr/recherche/unites/Ggb/images/0matmet/I-PCR-3S.presentation.pdf]

30. Groth AC, Calos MP: Phage integrases: biology and applications. J Mol Biol 2004, 335:667-678.

31. Poteete AR, Fenton AC, Nadkarni A: Chromosomal duplications and cointegrates generated by the bacteriophage lambda Red system in Escherichia coli K-I 2. BMC Mol Biol 2004, 1 3:5-22.

32. Khlebnikov A, Datsenko KA, Skaug T, Wanner BL, Keasling JD: Homogeneous expression of the $P_{B A D}$ promoter in Escherichia coli by constitutive expression of the low-affinity high-capacity AraE transporter. Microbiology 200I, I 47:324I-3247.

33. Muniesa M, Recktenwald J, Bielaszewska M, Karch H, Schmidt H Characterization of a shiga toxin 2e-converting bacteriophage from an Escherichia coli strain of human origin. Infect Immun 2000, 68:4850-4855.

34. Teel LD, Melton-Celsa AR, Schmitt CK, O'Brien AD: One of two copies of the gene for the activatable shiga toxin type $2 \mathrm{~d}$ in Escherichia coli 091:H2I strain B2FI is associated with an inducible bacteriophage. Infect Immun 2002, 70:4282-429I.

35. Aertsen A, Faster D, Michiels CW: Induction of Shiga toxin-converting prophage in Escherichia coli by high hydrostatic pressure. Appl Environ Microbiol 2005, 71:1 I55-II62.

36. Muniesa M, Blanco JE, De Simon M, Serra-Moreno R, Blanch AR, Jofre J: Diversity of stx2 converting bacteriophages induced from Shiga-toxin-producing Escherichia coli strains isolated from cattle. Microbiol 2004, I 50:2959-297|

37. Garcia-Aljaro C, Muniesa M, Blanco JE, Blanco M, Blanco J, Jofre J, Blanch AR: Characterization of Shiga toxin-producing Escherichia coli isolated from aquatic environments. FEMS Microbiol Lett 2005, 246:55-65.

38. Livny J, Friedman DI: Characterizing spontaneous induction of Stx encoding phages using a selectable reporter system. Mol Microbiol 2005, 5 1: 1691-1704.

39. Beloin C, Deighan P, Doyle M, Dorman Cl: Shigella flexneri 2a strain 2457T expresses three members of the H-NS-like protein family: characterization of the Sfh protein. Mol Genet Genomics 2003, 270:66-77. Epub

40. Rossi MS, Paquelin A, Ghigo JM, Wandersman C: Haemophoremediated signal transduction across the bacterial cell envelope in Serratia marcescens: The inducer and the transported substrate are different molecules. Mol Microbiol 2003, 48: $|467-| 480$.

41. Derbise A, Lesic B, Dacheux D, Ghigo JM, Carniel E: A rapid and simple method for inactivating chromosomal genes in Yersinia. FEMS Immunol Med Microbiol 2003, 38:113-116. 
42. Strauch E, Lurz R, Beutin L: Characterization of a Shiga toxinencoding temperate bacteriophage of Shigella sonnei. Infect Immun 200I, 69 1 2:7588-7595.

43. Pelludat C, Mirold S, Hardt WD: The SopEPhi phage integrates into the ssrA gene of Salmonella enterica serovar Typhimurium A36 and is closely related to the Fels-2 prophage. J Bacteriol 2003, 185:5|82-5191.

44. Gonzalez MD, Lichtensteiger CA, Caughlan R, Vimr ER: Conserved filamentous prophage in Escherichia coli OI 8:KI:H7 and Yersinia pestis biovar orientalis. J Bacteriol 2002, 184:6050-6055.

45. Hanahan D: Studies on transformation of Escherichia coli with plasmids. J Mol Biol 1983, 1664:557-580.

46. Rose RE: The nucleotide sequence of pACYCI 84. Nucleic Acids Res 1988, 16:355.

47. Sambrook J, Russell DW: Molecular Cloning: A Laboratory Manual 4th edition. Cold Spring Harbor Laboratory Press, Cold Spring Harbor, NY; 2001.

48. National Center for Biotechnology Information [http:// www.ncbi.nlm.nih.gov]

49. Muniesa M, Jofre J: Abundance in sewage of bacteriophages that infect Escherichia coli O 157:H7 and that carry the Shiga toxin 2 gene. Appl Environ Microbiol 1998, 64:2443-2448.

50. Russmann $\mathrm{H}$, Schmidt $\mathrm{H}$, Caprioli A, Karch $\mathrm{H}$ : Highly conserved Bsubunit genes of Shiga-like toxin II variants found in Escherichia coli OI57 strains. FEMS Microbiol Lett 1997, I I 8:335-340.

Publish with Bio Med Central and every scientist can read your work free of charge

"BioMed Central will be the most significant development for disseminating the results of biomedical research in our lifetime. "

Sir Paul Nurse, Cancer Research UK

Your research papers will be:

- available free of charge to the entire biomedical community

- peer reviewed and published immediately upon acceptance

- cited in PubMed and archived on PubMed Central

- yours - you keep the copyright

Submit your manuscript here:

http://www.biomedcentral.com/info/publishing_adv.asp
BioMedcentral 